San Jose State University

From the SelectedWorks of Karthika Sasikumar

April 3, 2019

\title{
India's Surgical Strikes: Response to Strategic Imperatives
}

Karthika Sasikumar, San Jose State University 


\section{INDIA'S SURGICAL STRIKES: RESPONSE TO STRATEGIC IMPERATIVES}

Karthika Sasikumar

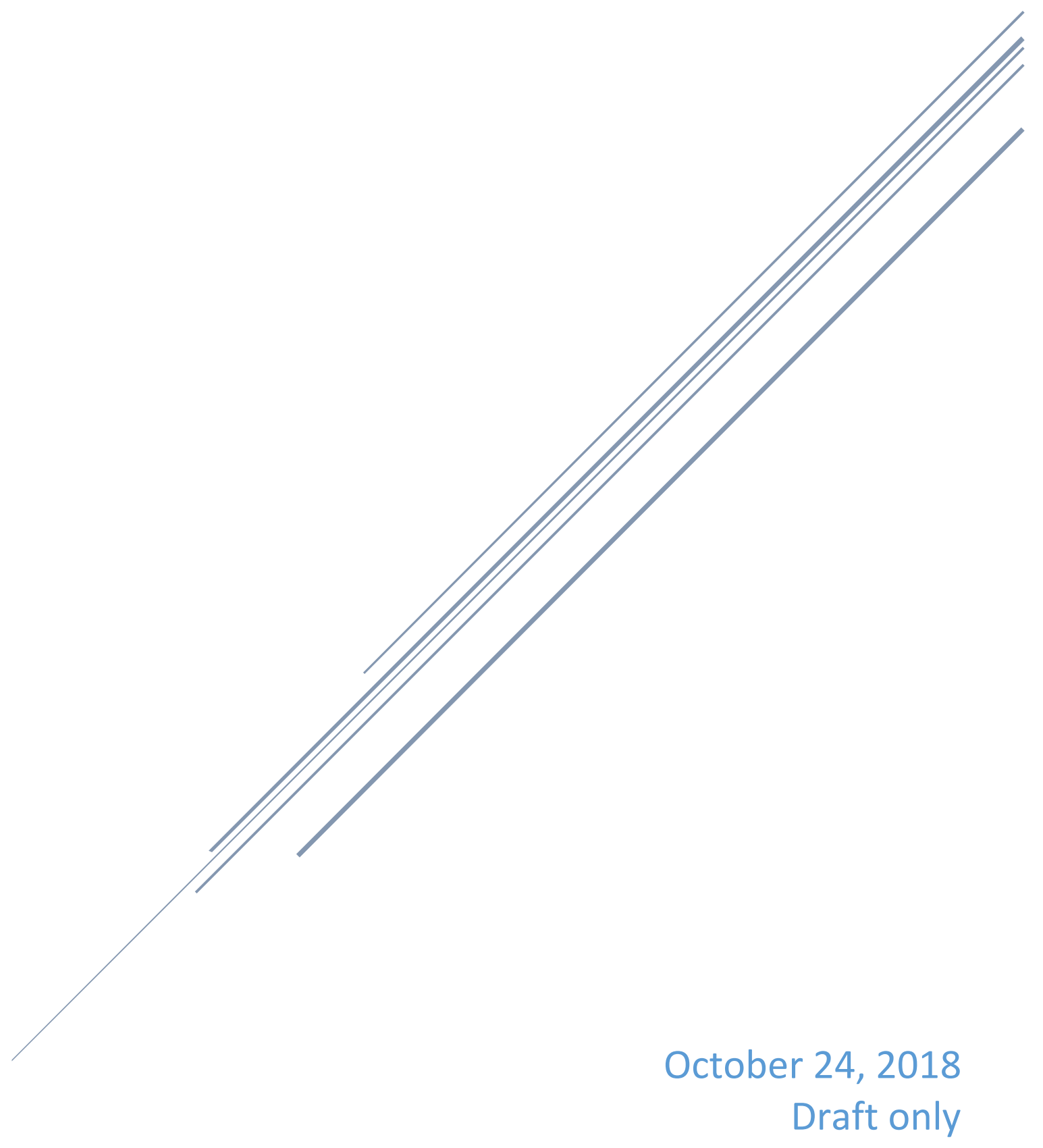




\section{Introduction}

On September 19, 2016, militants allegedly backed by Pakistan, attacked an Indian Army camp in Uri. The government in New Delhi, which was facing important regional elections, encountered intense public pressure to muster a military response. Such a response, however, ran the risk of triggering a nuclear exchange with devastating consequences. Ten days later, India reported that it had carried out "surgical strikes" on terrorist training camps in Pakistan-controlled territory. The paper examines this specific episode in India-Pakistan deterrence dynamics, focusing on the nomenclature "surgical strikes." It argues that the choice of the term itself is new and worthy of investigation. The significance of this investigation lies in the fact that the term 'surgical strike' can be useful for de-escalation and perception management in some circumstances, while engendering dangerous and destabilizing outcomes in others.

The first section briefly furnishes the strategic context of India-Pakistan nuclear deterrence, claiming that the surgical strikes are a response by India to the imperatives of the strategic situation. This section also describes the Uri attacks and India's military response. The second section identifies the various rhetorical moves by the Indian government that framed the response as a surgical strike, using qualitative content analysis of the official announcement of the operation. It also considers other statements in the media by high-ranking political and military leaders regarding the strikes. The third section shows how these statements were received by the domestic audience, by Pakistan, and by the international community. The concluding section sounds a note of caution about future iterations of so-called surgical strikes.

\section{Deterrence}

India and Pakistan tested nuclear weapons in May 1998; however, the two countries had already possessed nuclear warheads and delivery systems for several years. India justified its possession with reference to both Chinese and Pakistani nuclear capabilities. The Chinese threat is more of a longterm geopolitical challenge. Pakistan is the adversary that is more likely to probe Indian defenses, and support militants attacking key Indian interests. This section elaborates on the constraints that India faces as it comes up with responses to these Pakistani policies, i.e. its strategic imperatives.

Over twenty years ago, Ashley Tellis described the strategic situation between India and Pakistan as "ugly stability." The possibility of full-scale war is eliminated by the desire to avoid a nuclear exchange. At the same time, given that the adversaries have intense and unresolved conflicts, there are strong incentives for sub-strategic operations (e.g. sponsoring militant attacks and launching limited military operations) (Tellis 1997). Some scholars have applied the Cold War concept of the 'stability-instability paradox' to the India-Pakistan relationship: the more credible deterrence became at the strategic level, the more violence we would expect at the sub-strategic level (Ganguly 1995).

An alternative causal logic for the same behavior is proposed by Paul Kapur. Pakistani leaders bet that although India could use its conventional superiority to reverse Pakistani territorial gains, it will refrain, for fear of a nuclear attack. It is not stability but instability, "the danger of nuclear escalation, that allows weak, revisionist Pakistan to undertake limited conventional aggression against India in hopes of altering regional boundaries without provoking a full-scale Indian conventional response" 
(Kapur 2006:41). Kapur concludes that the stability-instability paradox is not the appropriate concept to explain India-Pakistan deterrence dynamics, and instead proposes the instability-instability paradox.

No matter which explanation one supports, decision-makers in New Delhi have to come up with policies to deter Pakistan's sub-strategic aggression. It is in their interest to signal that they would respond to such aggression with stringent conventional military responses. However, India wishes to avoid triggering escalation to the nuclear level. This fear of escalation, then, becomes an asset for Pakistani strategy. Given that Pakistan is inferior in conventional (non-nuclear) firepower, it has a powerful incentive to convey the message that it might respond to an Indian conventional attack with nuclear use. It is no surprise that Pakistan has refused to follow India in ruling out the first use of nuclear weapons. Pakistan's official and non-official statements have deliberately made the threshold for nuclear use (commonly referred to as the 'red line') low and ambiguous (Narang 2009/10, Tasleem 2016).

When terrorists attack Indian assets, Pakistan is often implicated as a supporter of the militants. The government in New Delhi faces immense (and growing) pressure from citizens to take decisive military action; however, it is only too aware of the risk that such action will trigger a nuclear response by Pakistan. It must come up with responses that assuage the public, soothe fears in the international community, deter future support by Pakistan, and stay under Pakistan's red lines. To this end, India has come up with various innovations in deterrence doctrine. Developments in the Cold War altered deterrence theory (Morgan 2011:148). Similarly, difficulties in practicing deterrence led India to redefine and employ concepts such as minimum deterrence, No First Use, and assured retaliation. While these innovations are intended to give India the freedom to maneuver in the shadow of nuclear weapons, some of them might be destabilizing.

In 1998 the Indian Prime Minister announced to Parliament that India would have a "minimum credible deterrent" and "a policy of No-First-Use and non-use against non-nuclear weapons states" (Vajpayee 1998). The No First Use declaration (NFU) and the credible minimum deterrent formulation together became the touchstones of policy. However, India's 2003 Draft Nuclear Doctrine clarifies that "minimum" is a "dynamic concept related to the strategic environment, technological imperatives and the needs of national security. The actual size of components, deployment and employment of nuclear forces will be decided in the light of these factors." The document also proposes that Indian warheads should be deployed on a triad of delivery vehicles (land, sea and air) (Arms Control Association 1999). The classical nuclear triad and the refusal to declare an upper limit on arsenal size, were seen at the time as incompatible with the idea of a minimum (Bajpai 1999). However, given India's strategic imperatives in the face of Pakistan's insistence on keeping its red lines unclear and low, such a redefinition of minimum is understandable. Similarly, there has been speculation that India's No First Use pledge has been modified, to allow for nuclear first use under some circumstances (Shukla 2017).

Another innovation is in the area of conventional doctrine. The Indian Army reportedly developed a plan (codenamed Cold Start) in 2010, calling for the swift mobilization. In response to cross-border incursions, select military units would take and hold small-scale gains in Pakistani territory (Ladwig III 2007 / 08). In turn, Pakistan is developing short-range missiles that could be used in the battlefield (Anon 2011, Chansoria 2014). According to some analysts, Pakistan's policy is leading to 
another shift in doctrine, towards a greater acceptance of counterforce strategies in Indian thinking (Lalwani and Haegeland 2017). Counterforce strategies, which would target Pakistan's nuclear assets such as warheads and missiles, are not necessarily incompatible with the massive retaliation strategy that was outlined in the 1999 Indian doctrine. During the Cold War, massive retaliation was usually equated with attacks on cities (or countervalue targeting). India may be modifying the strategy in accordance with its own strategic imperatives.

The choice of 'surgical strikes' is the most recent example of Indian 'learning' in response to the strategic imperatives in South Asia. These imperatives include: signaling to Pakistan that substrategic aggression will be punished, signaling to the international community that India is behaving as a responsible nuclear power and responding in a limited and justified manner, and signaling to the increasingly attentive and demanding domestic audience that the government is serious about countering cross-border terrorism. As Patrick Morgan points out in his study of deterrence as a Cold War practice, signaling credibility was burdensome and expensive, but in its absence, deterrence was expected to collapse. Morgan also draws our attention to the link between signaling credibility to the adversary and domestic political compulsions (the desire not to appear 'soft') (Morgan 2011:161). As will be clear in the next section, the military operations carried out in September 2016 were intended to send a signal to domestic, regional, and international audiences about India's preparedness to respond to cross-border incursions.

\section{Uri attacks and India's response}

Kashmir is the major point of contention between India and Pakistan. Kashmiri militants dissatisfied with India's administration found financial and military support across the border. The precise degree of involvement of Pakistani state agencies in this support is a matter of contention. Kashmir is divided by the Line of Control (LoC), the de facto border. It is the ceasefire line that was established by the Simla Agreement which ended the 1971 India-Pakistan war (as opposed to the International Border, a demarcation that neither state contests).

In an early morning attack on September 18, 2016, armed militants targeted an army camp in Uri, a garrison town close to Srinagar, the capital of Jammu and Kashmir (Indian Kashmir). 19 Indian soldiers, headed to take up positions guarding the LoC, were killed. The Indian government claimed that items bearing Pakistani markings were found at the site, and held the militant group Jaish-eMohammad responsible for the attack (Peri 2016). Later, a different organization, Lashkar-e-Taiba, was identified as carrying out the attack (Tiwary 2017).

Ten days later, between September 28 and 29, 2016, India struck back with simultaneous raids on camps in Pakistan Occupied Kashmir (PoK), where militants were allegedly being trained to carry out attacks in India. The Indian government, headed by the Bharatiya Janata Party (BJP) with Narendra Modi as Prime Minister, insisted on describing these military actions as "surgical strikes." One estimate is that 70-80 men on the Pakistan side (both uniformed personnel and others not in uniform) were killed in these raids (Gokhale 2017:loc. 735). Another estimate claims that 38-40 terrorists and two Pakistan Army personnel were killed (Aroor and Singh 2017:23). 


\section{India's framing of strikes}

Saloni Kapur rightly points out that 'surgical strike' is a "securitizing" phrase with contestable meaning (Kapur 2018:71). This section identifies the rhetorical strategies used by Indian decisionmakers to frame their response to the Uri attacks as a surgical strike.

\section{Surgical strikes: definition and criticism}

The term 'surgical strike' originated in the United States during the Vietnam War (Safire 1986). It has been gaining currency since the end of the Cold War, and was frequently used in the 1991 Gulf War, the 1999 war in Kosovo, and in Afghanistan and Iraq (Bissett 2003). Surgical strikes are associated with the technology of the so-called Revolution in Military Affairs. 'Prompt Global Strike' capability was developed to deliver conventional bombs anywhere in the world, ideally within an hour. Such strikes were intended to supplement, and potentially replace, both forward deployed troops and nuclear strikes (Woolf 2017).

Surgical strikes are also relevant in counterproliferation. In the mid-1990s, the Clinton administration reviewed a plan to conduct surgical strikes on the Yongbyon reactor in North Korea. However, it became obvious that the result of the surgical strike would be anything but surgical, as it could trigger an invasion of South Korea by the million-man North Korean army (Perry 2006:81). A decade later, surgical strikes were advocated against Iranian nuclear facilities which were suspected of producing fissile material for warheads (Kroenig 2012).

The concept of surgical strikes has also come in for criticism. A prominent social psychologist views the term as an example of sanitizing language, used to camouflage activities that might otherwise be seen as repugnant (Bandura 1999:195). Bissett reaffirms this view, and points out that the surgical metaphor carries connotations of science, precision, control, and asepsis. These values are at odds with the actualities of modern warfare, but the metaphor makes warfare seem more acceptable, even desirable. The concept of surgical strikes contains the additional attraction of a technical fix to a complex political problem (Bissett 2003). James der Derian describes this type of war as "virtuous," referring to the illusion that technical capability can "actualize violence from a distance," with minimal casualties, thus making the military action ethical (Der Derian 2001:xv).

\section{Was India's military response a surgical strike?}

The Indian government took pains to frame its response to the Uri attacks as a "surgical strike," as will be elaborated below. However, we cannot take the designation "surgical" as given. Indian defense commentator Mohan Guruswamy said that the BJP government's insistence on the term was "political charlatanism" (Guruswamy 2016). Pakistan's official military media wing claimed that casual cross-border firing was being re-branded as "surgical strikes" (Malhotra 2016). Considering the thrusts were shallow and did not involve airpower, Sandeep Singh prefers to describe them as "border raids" (Singh 2016). A retired Pakistan Army officer, Maj. Gen. Asad Durrani prefers the term "modified hot pursuit" (Dulat, Durrani and Sinha 2018).

Moreover, there is contestation over the actual events of September 2016. Saloni Kapur cites three different press reports: from the Times of India, the BBC, and the New York Times. Kapur reports that the Indian newspaper gives a sensational description of a raid by Indian commandos, while the article in the New York Times casts doubt on any significant action by the Indian military. The BBC's reportage describes certain operations by India, though they are not as dramatic as the Times of India 
piece (Kapur 2018). This paper does not take a position on the events that transpired, but seeks to investigate how they were portrayed and perceived.

\section{Surgical strikes in Indian strategy}

Critics of the ruling party in India claimed that similar operations had been carried out in the past, and that the BJP government had not done anything innovative or remarkable (Tharoor 2018). It is true that the term 'surgical strike' has not been used in a consistent manner in the writing of Indian strategic analysts, nor in government documents. Interestingly, in response to a query under the Right to Information Act, the Directorate General of Military Operations of the Indian Army stated that it does not have records of any surgical strike conducted before September 29, 2016 (Anon 2017).

In the face of terrorist incursions and public pressure to counter them, governments in New Delhi have been carrying out cross-border operations. The goal was to show that India was not paralyzed by the fear that Pakistan would quickly escalate the conflict. The Congress Party, now in opposition, issued a statement with three specific dates — October 1 2011, July 28 2013, and January 142014 when the Army had launched surgical strikes across the LoC (Manoj 2018). The Foreign Secretary in the previous Congress-led government, Shivshankar Menon, stated that such operations had not been publicized, "because they were not aimed at the domestic constituency" (Venu 2016). An opposition politician called the strikes "neither new, nor decisive, nor exceptional, not even surgical" (Tharoor 2018).

Although these arguments against viewing the surgical strikes as innovative must be taken into account, even critics agree that the publicity and framing of the military operation are unprecedented. When asked about previous such operations carried out by India, then Information and Broadcasting Minister Venkaiah Naidu pointed out that what set the raids of September 2016 apart was that the "government has sent a signal to Pakistan and the international community" (Sharma and Venugopal 2016).

Thus, what is innovative is not the choice to carry out focused raids on enemy-held territory, but the decision to publicize the operations and to designate them as surgical strikes. In June 2015, the Indian Army carried out a series of operations in the territory of its eastern neighbor, Myanmar, which were described at the time as 'surgical strikes.' The targets were two camps of the National Socialist Council of Nagaland-K, a militant outfit active in the northeastern border states of Manipur and Nagaland. At this time, a junior BJP minister, Rajyavardhan Rathore, went on television to warn that cross-border raids were also possible against Pakistan (Gokhale 2017:loc. 442).

\section{Putting the surgical in 'surgical strike': the DGMO press statement}

On September 29, 2016, the Director General of Military Operations (DGMO) of the Indian Army, Lt. Gen. Ranbir Singh, made a statement to the media, at a rare joint press conference of the Ministries of Defence and External Affairs. This statement deserves to be analyzed in detail as it reveals the ways in which the military action was framed as "surgical."

Singh stated (Anon 2016b, emphasis mine): 
Based on very credible and specific information which we received yesterday that some terrorist teams had positioned themselves at launch pads along the Line of Control with an aim to carry out infiltration and terrorist strikes in Jammu \& Kashmir and in various other metros in our country, the Indian army conducted surgical strikes last night at these launch pads. The operations were basically focused to ensure that these terrorists do not succeed in their design of infiltration and carrying out destruction and endangering the lives of citizens of our country.

The italicized words are all intended to convey an impression of precision, accuracy and intelligent targeting based on information about specific terrorist plots.

Interestingly, an alternative version of this statement reads: “...the Indian Army conducted surgical strikes at several of these launch pads to pre-empt infiltration by terrorists" (Anon 2016d). This version includes a mention of pre-emption, which is significant because pre-emption has a precise meaning in international law. It implies that an attack is imminent and that military force is being used as a last resort. It is not known why one version includes the word 'pre-emption,' however, the video recording of the press briefing does not include it. Siddharth Varadarajan asserted that "in legal terms, India has cast the strikes as pre-emptive self-defence" (Varadarajan 2016). However, Indian authorities eventually came up with the term "anticipatory self-defence," recognizing the problematic status of the term 'pre-emption' in international law (Begoore 2016).

The DGMO statement is carefully crafted to remove any impression that India was lashing out in anger:

The matter had been taken up at highest diplomatic levels and through military channels. India has also offered consular access to these apprehended terrorists for Pakistan to verify their confessions. Furthermore, we had proposed that fingerprints and DNA samples of terrorists killed in Punch and Uri could be made available to Pakistan for investigation. Despite our persistent urging that Pakistan respect its January 2004 commitment for not allowing its soil or territory under its control to be used for terrorism against India, there has been no let up.

This paragraph reinforces the idea that the strikes were a necessary intervention (similar to a medical intervention - note the clinical terms included), a last resort after the failure of diplomacy. The statement includes a signal of reassurance: "The operations aimed at neutralizing terrorists have since ceased. We do not have any plans for further continuation." This sentence affirms that the military operation had limited, tactical goals, and that it did not directly target Pakistan.

The statement concludes with a clear signal that the strikes were a demonstration of a larger determination to push back against Pakistani adventurism. The conclusion, at the same time extends an offer to cooperate:

... the Indian Armed Forces are fully prepared for any contingency that may arise. It is India's intention to maintain peace and tranquillity in the region. But we cannot allow the terrorists to operate across the Line of Control with impunity and attack citizens of our country at will... we expect the Pakistani army to cooperate with us to erase the menace of terrorism from the region.

\section{Other statements on surgical strikes}

In order to identify statements on the surgical strikes by important decision-makers, a systematic study of one newspaper (The Times of India) was carried out. A computer program was used to identify all the articles with titles containing the following terms: pathankot, uri, attack*** (any form of this word), surgical strike, jammu, j\&k, army, security, pakistan, terror***(any form of this word). 
The time period was from September 2016 to March 2017. The program then checked for the term 'Uri' in the content of the article (to eliminate references to surgical strikes that dealt with nonsecurity related topics). A set of 52 articles was generated through this process, helping to identify direct quotations from individuals, who were at the time verified top members of the BJP. A study of these quotations shows that the government framed the strikes as responses to a specific incursion, in Uri, but promised that they would have a deterrent effect on Pakistan's support for terrorism. At the same time, the government was aware of the potential for domestic Indian rhetoric to provoke an unwanted reaction from Pakistan, and tried to exert control over the situation.

In his very first reaction to the Uri attacks, Prime Minister Narendra Modi promised that the perpetrators of the attack would be punished (Anon 2016g). The Chief Minister of Goa demanded that the national government adopt "a more offensive stance" (Anon 2016a). Party officials went further. Ram Madhav, the National General Secretary of the BJP, stated that the days of strategic restraint were at an end and promised an asymmetrical response to Pakistan: "For one tooth, the complete jaw" (Neelakantan 2016b). The Defence Minister commented specifically that India would not be deterred by Pakistan's possession of nuclear weapons (Anon 2016f). Thus, the foundation for a military response was laid.

It is important to note that at the same time, notes of caution were sounded. Former Indian Army Chief and the Minister of State for External Affairs, V.K. Singh stated the Indian response had "to be taken without getting influenced by emotions, anger. It has to be taken coolly and with proper planning" (Anon 2016e). Once the strikes had been announced, the Prime Minister himself cautioned his ministers against "chest thumping" (Neelakantan 2016a).

These statements show that the Indian government was well aware of the dangers of escalation based on provocative statements, and wanted to keep control over the rhetorical arena. Further evidence that official statements were carefully controlled was found in an analysis of tweets by BJP members of Parliament (either Lok Sabha or Rajya Sabha), and/or BJP national office-bearers as identified on the party's website. In this Twitter sample, in the period August 1, 2016 to March 31, 2017 there were no co-occurrences of the terms 'UP' or 'Uttar Pradesh,' with the terms referring to the Uri attacks or surgical strikes. Elections were being held in UP during this period, yet BJP leaders were restrained from explicitly referencing the strikes in election-related tweets. However, the election campaign did make use of other methods (such as billboards) to reference the strikes (Sasikumar and Verniers 2018).

The government publicized the military operation in other innovative ways. In June 2018, a video purporting to show the surgical strikes in real time was released. Although the video was supposedly leaked, the military confirmed its authenticity (Singh 2018). In September 2018, an official video was released in an attempt to prove that the strikes had indeed taken place. This intervention is the result of new technology, and the central role played by video in media consumption worldwide. At the same time, these releases confirm that the government remains heavily invested, two years after the fact, in portraying the military operation as consequential, and rebutting allegations that the raids did not take place.

Another unprecedented development was the publication in 2018, of a portrait of the lead soldier in the surgical strikes in a general non-fiction paperback book. The first account in the compilation 
India's Most Fearless, gave details of the 2016 raid while hiding the true identity of the Army major (Aroor and Singh 2017). Finally, as the second anniversary of the operation approached, the Defence Ministry declared September 29 as Surgical Strikes Day, and events were organized across the country to mark the occasion. Critics alleged that these events sought to generate "fake nationalism" through repeated invocations of the surgical strikes (Joshi 2018)

\section{The reactions to surgical strikes}

In this section, the responses by Indian domestic audiences, the Pakistani government, and the international community are documented. It appears that all three of these audiences reacted in the manner that the Modi government had anticipated.

\section{Indian domestic audiences}

As noted above, the official statement issued in the aftermath of the strikes, strove to present the military action as motivated solely by national interest and free of party politics. However, it is important to situate the surgical strikes in the domestic context. While a comprehensive analysis of the foreign policy of the BJP government, even in the arena of India-Pakistan relations, is outside the purview of this paper, this sub-section shows that the dominant narrative of the surgical strikes fortified the position of the government in three ways. First, the media strengthened the image of the BJP as the 'party of national security,' by reinforcing the idea that the strikes were an appropriate response to Pakistan's provocations and would deter them in the future. Second, election results from a key state election show that this dominant narrative was accepted by the majority. Third, the term 'surgical strike' successfully permeated the political discourse, as shown in the discussion of demonetization.

There has always been concern that domestic politics would fuel inadvertent escalation between India and Pakistan. The mediatization of the relationship-by which I mean the heightened role of print and particularly electronic media in presenting facts and opinions to the informed publicmakes the maintenance of stability more difficult. The increase in prosperity and education in India, led to a rise in the number of news channels. A recent study found that there were 400 television news channels in India. While the study did not find evidence that the media directly influenced policy-making, it was influential in "communicating crisis narratives and amplifying the consequences of crises." In its examination of media portrayal of the surgical strikes, this study claimed that the media amplified the government's narrative on the events and significance of the military operations (Neog 2018).

The term 'surgical strikes' "dominated prime-time debates, social media chatter and dinner-table conversations" (Guruswamy 2016). In their painstaking analysis of primetime news items on the top two television channels, during and after the surgical strikes, Sushmita Pandit and Saayan Chattopadhyay show that the television news (both in English and Hindi) used a variety of rhetorical strategies to portray the Indian public as completely united in support of the government. Any questioning of the need for, or the results of, the surgical strikes was criticized, not only by the government spokespersons appearing on the shows, but the television anchors themselves (Pandit 
and Chattopadhyay 2018). The government's chosen frame was successful in being adopted by the informed public.

Elections provide a stringent test of the reception of a government policy. Campaigning for statelevel elections began in Uttar Pradesh (UP), India's most populous state, in November 2017. Elections were held in February and March 2017. The BJP won 312 of the 403 seats in the Uttar Pradesh Assembly and 40\% of the votes cast (Verniers 2017). In a pre-election poll of close to 38,000 voters, a vast majority ( 90 per cent) of UP voters approved of the strikes. About the same percentage said that Modi had emerged stronger as a result of the action. When asked specifically whether the surgical strikes would help the BJP at the hustings, 67 per cent predicted that they would (Jha 2016).

It is not possible to state definitively that the strikes brought about the BJP's victory. Other factors contributed; for instance, the shakiness of the alliance between its rivals - the Congress and the Samajwadi Party (Farooqui and Sridharan 2017). While the number of undecided voters is on the rise, the BJP's competitors continued to implement caste-centric strategies, which are now less effective compared to the charismatic leadership and broad party image (Verniers 2017). Neither is it possible to cite the victory as evidence that citizens approved of the strikes: a poll conducted in UP in December 2016 found that only two-thirds of the respondents had heard about the strikes (Lokniti 2017). However, as Saloni Kapur points out, we can at the very least see the electoral verdict as acceptance of the ruling regime's rhetorical framing of the strikes (Kapur 2018:70).

Surgical strikes not only appear to have solved the dilemma of responding to sub-strategic provocation in a nuclear relationship, but also are in consonance with the image that Narendra Modi, who dominates foreign policy making in the BJP government, seeks to project. Modi cultivates the image of a leader willing to take difficult, risky, and initially unpopular decisions in the national interest. His hallmark is a technocratic style of governance (Ruparelia 2015). The swift, technology-reliant surgical strikes exemplified Modi's modus operandi. A similar move in the financial sector was demonetization. In November 2016, weeks after the surgical strikes, Modi announced that specific currency notes (of Rs. 500 and Rs. 1000 value) would no longer be legal tender. Home Minister Rajnath Singh declared: "Rs 500 and Rs 1,000 notes gave strength to those patronising terrorism. PM has taken away this strength by this ban. Fake Indian currency notes are printed in Pakistan and circulated in the country to destroy its economy" (Anon 2016c). Here demonetization is portrayed as a smart move to remove these notes from circulation, thereby reducing terrorism and frustrating Pakistan's plans. Finally, Singh described demonetization itself as a surgical strike: "... a surgical strike has been conducted on corruption" (Anon 2016c).

\section{Pakistan's reaction}

Pakistan flatly denied that a cross-border strike had taken place in September 2016, saying merely that Indian troops had fired small arms across the LoC, killing two soldiers and injuring nine. The Inter Services Public Relations, the media wing of the Pakistan military, described this cross-border firing as an "existential phenomenon," whereas a strike on Pakistani soil would have elicited a strong response (Malhotra 2016, emphasis mine). The New York Times quoted a senior Pakistani official, speaking on the condition of anonymity because he was not authorized to speak publicly, asserting that Pakistan would have considered a cross-border strike "an act of war" (Barry and Masood 2016). 
By differentiating the location of the camps abutting the LoC, from real Pakistani soil, the Pakistani government was able to minimize the significance of the strikes.

Leaders in Islamabad chose the face-saving device of denying that a significant strike had been carried out. They seem to have understood and accepted that their Indian counterparts were signaling a limited response. "The Indian military was wiser and didn't go for a deeper strike. They just fulfilled the wishes of the political leadership without causing any major disaster," said Maj. Gen. Mahmud Ali Durrani, a former ambassador to the United States (Gowen 2016). Durrani also commended the Pakistan government for its muted reaction (Dulat, Durrani and Sinha 2018).

\section{Reaction from the international community}

The framing of the operation as a surgical strike helped to foster the impression that India's reaction was proportionate, limited, and not a prelude to escalation. India argued that its response was justified under international law because it was in self-defense, specifically referring to the emerging post-9/11 international norm that holds states responsible for providing safe haven to non-state actors who attack other states (Begoore 2016). This argument seems to have resonated, since there were no condemnations of the strikes by major powers.

The day after the Uri attack, then US Secretary of State John Kerry spoke with his Indian counterpart and while condemning terrorism, also cautioned against escalation. After the surgical strikes, the US Ambassador to India, who was visiting Washington DC, rushed back to India. The United States reiterated its concerns about terrorism and called for India and Pakistan to maintain channels of communication. When asked specifically whether the United States considered the surgical strikes an instance of escalation, the State Department spokesperson refused to "characterize" it (Anon 2016h). Siddharth Varadarajan interprets this as tacit acceptance of Indian actions by the United States. Pakistan's denial that a major raid took place also allowed other major powers to reserve judgment on India's actions (Varadarajan 2016).

\section{The dangers of surgical strikes}

The second section showed how the military operation in 2016 was framed as a surgical strike. This was an innovation in terminology that allowed India to assuage the public, soothe fears in the international community, deter future support by Pakistan, and stay under Pakistan's red lines. The third section demonstrated that key audiences responded as intended to the BJP government's surgical strike framing. However, this consonance may not obtain in the future. This section lists three flaws inherent in the concept of surgical strikes, which exacerbate the instability of the IndiaPakistan nuclear deterrence relationship.

\section{False promises of precision and efficacy}

In the long term, surgical strikes are intended to deter Pakistan from continuing its support to militants planning attacks on Indian assets, thus reducing infiltration and terrorism. The government 
claimed that the strikes led to a decline in infiltration (Biswas 2017). However, another measure of stability, cross-border firing, was reportedly at a higher level than before the strikes (Banerjee 2018). Moreover, just weeks after the surgical strikes, there was another attack on an Indian Army camp in Nagrota, Jammu (Yasir 2016). Strikes are unlikely to be effective in the medium to long-term in stabilizing the strategic situation. It is far from given that Pakistani leaders are able to control militant groups (even if they are willing to rein them in)(Dalton and Perkovich 2016, Popovic 2015). Finally, even in the absence of foreign infiltration, terrorist attacks in India are likely to continue. This might lead to frustration among the Indian public, and calls for more stringent action.

Surgical strikes exacerbate the destabilizing presence of non-state actors in the India-Pakistan relationship, where risks of war are heightened by incomplete information and incentives for states to misrepresent their ties to non-state violent actors (Bapat 2014). In the short term, framing a military action as a surgical strike aims to reassure the adversary and other foreign players that it is a rational, precise, and limited response to a specific provocation. Surgical strikes are devised to stay under Pakistan's threshold for nuclear use. Yet this threshold is unclear and shifting, based on a host of factors such as leaders' personalities, civil-military relations, economic swings, electoral cycles, and relations with extra-regional powers such as China, Russia, Saudi Arabia, and the United States. The risk that Pakistan will react with a nuclear strike on India cannot be eliminated, and the impression of clinical precision inherent in the term "surgical" may lull Indian decision-makers into ignoring that risk.

\section{The ratchet effect of iterated surgical strikes}

These risks are multiplied when we take into consideration the effect that repeated surgical strikes will have on the calculations of Pakistani decision-makers. Having suffered the cumulative effects of limited strikes, they are likely to become extremely reactive and adopt pre-emptive strategies.

Worries about the vulnerability of Pakistan's relatively small nuclear arsenal will be magnified by repeated small-scale Indian military operations. The 'use it or lose it' mentality when it comes to the arsenal will lead Islamabad to move sooner to the next rung in the escalation ladder. Indian elites are cognizant of this danger, of course, but they are unlikely to have enough information about specific preferences and plans. The illusion that surgical strikes will always be perceived as such in Pakistan as well as India, is a dangerous and destabilizing one.

\section{Mixed messages and multiple audiences}

Clarity is very important in deterrent communication. Speeches, statements, published doctrines, and military operations "speak for" what are, in effect, mute nuclear weapons (McCanles 1984:14). For instance, we note that there is confusion about whether the surgical strikes crossed the LoC. The press briefing by the Indian Army's Director General of Military Operations (DGMO) describes the strikes as occuring along and not across the LoC, although the consensus is that these were crossborder strikes. Unofficially, the army says the strikes targeted seven different "terrorist launch pads," at a distance of half to one kilometer across the LoC (Varadarajan 2016). Crossing the LoC is considered a 'firebreak,' or a major rung on the escalation ladder, as seen in the Pakistani government's insistence that the operation did not take place on Pakistani soil. Therefore, ambiguity about the definition and intended goals of a surgical strike is dangerous.

Unlike in the Cold War where the United States and the Soviet Union were in dialogue primarily with each other, India-Pakistan deterrence includes sub-state (militant groups) and extra-regional 
actors (major powers). Consequently, the messages that leaders wish to convey through signaling become 'mixed messages.' One could imagine a scenario in which the Pakistani military pulls back in the face of a credible threat by India, but the same massive threat pushes militants over the edge and triggers a surge in suicide attacks.

Since 'surgical strike' is an inherently ambiguous term, it may both reassure and frighten. The United States in 2016 seemed to be in accord with India's justification for the strike, but may differ in the future. In fact, Sandeep Singh argues that Pakistan set a trap for India with the Uri attacks. The Indian strategic community was "restive," wanting to lash back at Pakistan, and walked into the trap, by carrying out the cross-border raids (Singh 2016). The implication is that India could have, inadvertently lost legitimacy with an important strategic partner, the United States.

\section{Conclusion}

The term 'surgical strike' carries the connotation of a necessary, well-planned intervention targeting a specific area or actor. It signals to the adversary that the action was deliberately restrained and is intended to avoid escalation. If Indian elites believe that their military operations across the border amount to surgical strikes, they are more likely to conduct them. However, the adversary may disagree as to whether a military action should be designated as a surgical strike, and may perceive it as crossing the 'red line' that justifies nuclear use. This paper examines one specific incident in depth, to illustrate that the Indian government attempted to frame its military operation as a surgical strike, that Pakistan and other audiences chose to accept it as such, but that surgical strikes can be destabilizing in different circumstances.

Anon. 2011, "Pakistan's New Missile Aimed at India's 'Cold Start' Doctrine: Experts" Economic Times. Retrieved June 19, 2011 (http:/ / articles.economictimes.indiatimes.com/2011-0420/news/29450960 1 nuclear-warheads-missile-system-doctrine).

Anon. 2016a, "C.M. Condemns J\&K Attack, Suggests Being More Offensive ": Times of India. Retrieved October 24, 2018 (http:/ / timesofindia.indiatimes.com//city/goa/CM-condemnsJK-attack-suggests-being-more-offensive/articleshow/54397790.cms).

Anon. 2016b, "India’s Surgical Strikes across Lo.C: Full Statement by D.G.M.O Lt Gen Ranbir Singh": Hindustan Times. Retrieved March 27, 2018 (https://www.hindustantimes.com/india-news/india-s-surgical-strikes-across-loc-fullstatement-by-dgmo-lt-gen-ranbir-singh/story-Q5yrp0gjvxKPGazDzAnVsM.html). 
Anon. 2016c, "Scrapping of Notes an Attack on Terror": Times of India. Retrieved June 12, 2018 (http://timesofindia.indiatimes.com//city/kanpur/Scrapping-of-notes-an-attack-onterror/articleshow/55345947.cms).

Anon. 2016d, "Surgical Strikes: Full Text of Indian Army D.G.M.O. Lt Gen Ranbir Singh's Press Conference": Indian Express. Retrieved January 5, 2018 (http://indianexpress.com/article/india/india-news-india/pakistan-infiltration-attemptsindian-army-surgical-strikes-line-of-control-jammu-and-kashmir-uri-poonch-pok-3055874/).

Anon. 2016e, "V.K. Singh Calls for Probe into Lacunas Which Led to Uri Attack": Times of India.

Retrieved October 24, 2018 (https:/ / timesofindia.indiatimes.com/india/VK-Singh-calls-forprobe-into-lacunas-which-led-to-Uri-attack/articleshow/54405818.cms).

Anon. 2016f, "P. M. Modi's Vow to Avenge Uri Won't Remain Just Words: Manohar Parrikar": Times of India. Retrieved October 24, 2018

(https:/ / timesofindia.indiatimes.com/india/PM-Modis-vow-to-avenge-Uri-wont-remainjust-words-Manohar-Parrikar/articleshow/54456254.cms?).

Anon. 2016g, "Those Behind Uri Terror Attack Won't Go Unpunished, Says Prime Minister Narendra Modi": Times of India. Retrieved October 24, 2018 (http://timesofindia.indiatimes.com//india/Those-behind-Uri-terror-attack-wont-gounpunished-says-Prime-Minister-Narendra-Modi/articleshow/54390848.cms).

Anon. 2016h, "What the U.S. State Department Is Saying About India's 'Surgical Strikes'": The Wire. Retrieved June 10, 2018 (https://thewire.in/external-affairs/us-state-departmentsaying-indias-surgical-strikes).

Anon. 2017, "No Records of Any Previous 'Surgical Strike': D.G.M.O in R.T.I Reply": Daily News and Analysis. Retrieved March 27, 2018 (http://www.dnaindia.com/india/report-norecords-of-any-previous-surgical-strike-dgmo-in-rti-reply-2541059).

Arms Control Association. 1999, "India's Draft Nuclear Doctrine": Arms Control Association. Retrieved October 24, 2018 (https://www.armscontrol.org/act/1999 07-08/ffja99).

Aroor, Shiv and Rahul Singh. 2017. India's Most Fearless: True Stories of Modern Military Heroes. Gurgaon: Penguin Random House India.

Bajpai, Kanti. 1999. "A Flawed Doctrine." Pp. 14 in Times of India. Mumbai.

Bandura, Albert. 1999. "Moral Disengagement in the Perpetration of Inhumanities." Personality \& Social Psychology Review 3(3):193-210.

Banerjee, Ajay. 2018, "2 Yrs Post 'Surgical Strikes', Firing across Loc up 4 Times": The Tribune. Retrieved October 24, 2018 (https://www.tribuneindia.com/news/jammu-kashmir/2-yrspost-surgical-strikes--firing-across-loc-up-4-times/659579.html).

Bapat, Navin. 2014. "The Escalation of Terrorism: Microlevel Violence and Interstate Conflict." International Interactions 40(4):568-78.

Barry, Ellen and Salman Masood. 2016, "India Claims 'Surgical Strikes' across Line of Control in Kashmir": New York Times. Retrieved June 11, 2018 (https://www.nytimes.com/2016/09/30/world/asia/kashmir-india-pakistan.html).

Begoore, Yateesh. 2016, "An Apologia for India's "Surgical Strikes" against Terrorist Groups: The Conflict with Pakistan". Retrieved June 11, 2018 (https://www.justsecurity.org/33409/apologia-indias-surgical-strikes-pakistan/).

Bissett, A. K. 2003. "High Technology War and 'Surgical Strikes' ". ACM SIGCAS Computers and Society 33(4).

Biswas, Tanima. 2017, "Infiltration Declined by 45\% after Surgical Strikes, Says Rajnath Singh": NDTV. Retrieved October 24, 2018 (https://www.ndtv.com/india-news/infiltrationdeclined-by-45-percent-after-surgical-strikes-says-rajnath-1707427). 
Chansoria, Monika. 2014, "Pakistan's Tactical Nukes Threaten Stability in South Asia":

foreignpolicy.com. Retrieved January 31, 2015

(http:// foreignpolicy.com/2014/05/05/pakistans-tactical-nukes-threaten-stability-in-southasia/).

Dalton, Toby and George Perkovich. 2016. Not War, Not Peace?: Motivating Pakistan to Prevent CrossBorder Terrorism: Oxford University Press.

Der Derian, James. 2001. Virtuous W ar: Mapping the Military-Industrial-Media-Entertainment-Complex. Boulder, CO: Westview Press.

Dulat, A. S., Asad Durrani and Aditya Sinha. 2018. The Spy Chronicles: R.A.W., I.S.I. And the Illusion of Peace. New Delhi: HarperCollins.

Farooqui, Adnan and E. Sridharan. 2017. "Uttar Pradesh Elections 2017: Failure of Pre-Electoral Coalition." Economic and Political Weekly 52(15):16-20.

Ganguly, Sumit. 1995. "Indo-Pakistani Nuclear Issues and the Stability/Instability Paradox." Studies in Conflict and Terrorism 18:325-34.

Gokhale, Nitin. 2017. Securing India the Modi Way: Pathankot, Surgical Strikes and More. New Delhi: Bloomsbury India.

Gowen, Annie. 2016, "India's 'Surgical Strike' on Pakistan Territory Hints at New Era for NuclearArmed Rivals": Washington Post. Retrieved June 11, 2018 (https://www.washingtonpost.com/world/asia pacific/indias-surgical-strike-on-pakistanterritory-hints-at-new-era-for-nuclear-armed-rivals/2016/09/30/98dadbc1-7528-4892-bc099ecaafebb301 story.html?utm term $=. \mathrm{d} 5 \mathrm{~d} 084 \mathrm{~b} 158 \mathrm{c} 9)$ ).

Guruswamy, Mohan. 2016, "What a Surgical Strike Really Is (and Why the Army Action across the L.O.C. May Not Qualify as One": Scroll. Retrieved March 10, 2018 (https://scroll.in/article/818398/what-a-surgical-strike-really-is-and-why-the-army-actionacross-the-loc-may-not-qualify-as-one).

Jha, Ajit Kumar. 2016, "Saffron Strike". Retrieved January 3, 2018 (http://indiatoday.intoday.in/story/bjp-uttar-pradesh-uttarakhand-punjab-akhilesh-kumarmayawati-narendra-modi/1/785764.html).

Joshi, Manoj. 2018, "'Surgical Strikes Day' Is Just a Pre-Election Dose of Patriotic Political Fodder": The Wire. Retrieved October 24, 2018 (https:/ thewire.in/politics/ugc-surgical-strikes-dayelection-political-fodder).

Kapur, S.Paul. 2006. Dangerous Deterrent: Nuclear Weapons Proliferation and Conflict in South Asia. Stanford: Stanford University Press.

Kapur, Saloni. 2018. "From Copenhagen to Uri and across the Line of Control: India's 'Surgical Strikes' as a Case of Securitisation in Two Acts." Global Discourse 8(1):62-79.

Kroenig, Matthew. 2012. "Time to Attack Iran: Why a Strike Is the Least Bad Option." Foreign Affairs:76-86.

Ladwig III, Walter C. 2007/ 08. "A Cold Start for Hot Wars?". International Security 32(3):158-90.

Lalwani, Sameer and Hannah Haegeland. 2017, "The Debate over Indian Nuclear Strategy Is Heating Up": War on the Rocks. Retrieved October 24, 2018 (https://warontherocks.com/2017/04/the-debate-over-indian-nuclear-strategy-is-heatingup/).

Lokniti. 2017, "Uttar Pradesh Pre-Election Tracker Survey, December 2016": Centre for Study of Developing Societies. Retrieved March 26, 2018 (http://www.lokniti.org/pdf/UttarPradesh-Pre-Election-Tracker-Survey-December-2016.pdf).

Malhotra, Hansa. 2016, "Time for Revenge’: Pak Fights Twitter War over Surgical Strikes": The Quint. Retrieved June 11, 2018 (https:/ /www.thequint.com/news/india/how-pakistan-is- 
reacting-surgical-strikes-across-loc-uri-attack-ranbir-singh-indian-army-dgmo-twitterfacebook-pok).

Manoj, C. L. 2018, "Cross-L.O.C. Actions Happened During U.P.A. Rule Too, Confirms A.K. Antony": Economic Times. Retrieved October 24, 2018 (https:/ / economictimes.indiatimes.com/news/defence/cross-loc-actions-happened-duringupa-rule-too-confirms-ak-antony/articleshow/54705268.cms).

McCanles, Michael. 1984. "Machiavelli and the Paradoxes of Deterrence." diacritics (14):12-19.

Morgan, Patrick M. 2011. "The Practice of Deterrence." Pp. 139-73 in International Practices, edited by E. Adler and V. Pouliot. Cambridge: Cambridge University Press.

Narang, Vipin. 2009/10. "Posturing for Peace? Pakistan's Nuclear Postures and South Asian Stability." International Security 34(3):38-78.

Neelakantan, Shailaja. 2016a, "Surgical Strikes: India, Pak N.S.A.S' Talk Led to P.M. Modi's 'No Chest-Thumping' Diktat, Pak Media Says ": Times of India. Retrieved October 24, 2018 (https://timesofindia.indiatimes.com/india/Surgical-strikes-India-Pak-NSAs-talk-led-to-PMModis-no-chest-thumping-diktat-Pak-media-says/articleshow/54778034.cms?).

Neelakantan, Shailaja. 2016b, "Uri Terror Attack: No More Tooth for Tooth, 'for One Tooth, Complete Jaw', Says B.J.P's Ram Madhav ": Times of India. Retrieved October 24, 2018 (http:/ / timesofindia.indiatimes.com//world/pakistan/Uri-terror-attack-No-more-tooth-fortooth-for-one-tooth-complete-jaw-says-BJPs-Ram-Madhav/articleshow/54402292.cms).

Neog, Ruhee. 2018. "Self-Referencing the News: Media, Policymaking, and Public Opinion in IndiaPakistan Crises." Pp. 115-42 in Investigating Crises: South Asia's Lessons, Evolving Dynamics, and Trajectories, edited by S. Lalwani and H. Haegeland. Washington D.C.: Stimson Center.

Pandit, Sushmita and Saayan Chattopadhyay. 2018. "Nationalism, Journalistic Discourse and IndiaPakistan Conflict." Journalism Practice 12(2):162-76.

Peri, Dinakar. 2016, "J.E.M Hand Seen in Uri Attack; D.G.M.O. Calls Pak Counterpart": The Hindu. Retrieved March 26, 2018 (http://www.thehindu.com/news/national/otherstates/JeM-hand-seen-in-Uri-attack-DGMO-calls-Pak-counterpart/article14986871.ece).

Perry, William J. 2006. "Proliferation on the Peninsula: Five North Korean Nuclear Crises." The Annals of the American Academy of Political and Social Science 607:78-86.

Popovic, Milos. 2015. "The Perils of Weak Organization: Explaining Loyalty and Defection of Militant Organizations toward Pakistan." Studies in Conflict and Terrorism 38:919-37.

Ruparelia, Sanjay. 2015. "Minimum Government, Maximum Governance': The Restructuring of Power in Modi's India." South Asia: Journal of South Asian Studies 38(4):755-75. doi: 10.1080/00856401.2015.1089974.

Safire, William. 1986. "On Language; on Surgical Strike." in New York Times.

Sasikumar, Karthika and Gilles Verniers. 2018. "Ballot Boxes and Surgical Strikes: Indian National Security Choices in an Election Campaign." in Annual Convention of the International Studies Association. San Francisco.

Sharma, Aman and Vasudha Venugopal. 2016, "Pakistan Is Like a Thief Bitten by a Scorpion, Cannot Cry out Even When in Pain: Venkaiah Naidu": Times of India. Retrieved October 24, 2018 (https:/ timesofindia.indiatimes.com//india/Pakistan-is-like-a-thief-bitten-by-ascorpion-cannot-cry-out-even-when-in-pain-M-VenkaiahNaidu/articleshow/54668326.cms).

Shukla, Ajai. 2017, "Speculation in Washington About Nuclear Doctrinal Changes by India": Business Standard. Retrieved March 27, 2018 (http://www.businessstandard.com/article/current-affairs/speculation-in-washington-about-nuclear-doctrinalchanges-by-india-117032101292 1.html). 
Singh, Sandeep. 2016, "India's Surgical Strikes: Walking into Pakistan's Trap?": The Diplomat.

Retrieved June 11, 2018 (https://thediplomat.com/2016/10/indias-surgical-strikes-walkinginto-pakistans-trap/).

Singh, Sushant. 2018, "What the Video Conceals": Indian Express. Retrieved July 10, 2018 (https://indianexpress.com/article/opinion/columns/surgical-strikes-video-pakistanpakistan-border-indian-army-5244596/).

Tasleem, Sadia. 2016, "Pakistan's Nuclear Use Doctrine": Carnegie Endowment for International Peace. Retrieved March 26, 2018 (http:// carnegieendowment.org/2016/06/30/pakistan-snuclear-use-doctrine-pub-63913).

Tellis, Ashley. 1997. "Stability in South Asia " Vol. Santa Monica, CA: RAND.

Tharoor, Shashi. 2018, "Surgical Strikes Day: If Govt Had Any Shame, It Would Have Shut Up": The Quint. Retrieved October 24, 2018.

Tiwary, Deeptiman. 2017, "Lashkar-E-Toiba Behind Uri Attack, Says N.I.A". Retrieved March 26, 2018 (http://indianexpress.com/article/india/lashkar-e-toiba-behind-uri-attack-says-nia4482725/).

Vajpayee, Atal Behari. 1998, "Prime Minister's Statement in Parliament on Bilateral Talks with the United States": Indian Embassy, Washington D.C. Retrieved May 11, 2004 (http://www.indianembassy.org/India Review/2005/August2005.pdf).

Varadarajan, Siddharth. 2016, "Indian Surgical Strikes against Terrorists in Pakistan: What We Know, What We Don't Know": The Wire. Retrieved June 11, 2018 (https://thewire.in/diplomacy/surgical-strikes-know-dont-know).

Venu, M. K. 2016, "Modi and B.J.P. Are Openly Politicising National Security, after Saying They Will Not": The Wire. Retrieved July 21, 2017 (https://thewire.in/72757/modi-bjp-nationalsecurity/).

Verniers, Gilles. 2017, "The Rise of the Floating Voter": The Indian Express. Retrieved March 26, 2018 (http://indianexpress.com/article/opinion/columns/uttar-pradesh-assembly-electionresults-2017-bjp-congress-political-parties-castes-4567215/).

Woolf, Amy F. 2017. "Conventional Prompt Global Strike and Long-Range Ballistic Missiles: Background and Issues." Vol. Washington DC: Congressional Research Service.

Yasir, Sameer. 2016, "Nagrota Attack: Surgical Strikes Had No Effect as Militant Infiltration Continues": First Post. Retrieved October 24, 2018 (https://www.firstpost.com/india/nagrota-attack-surgical-strikes-had-no-effect-as-militantinfiltration-continues-3129868.html). 